incident $\mathrm{CV}$ event and death. Event-free survival rates were compared using Kaplan-Meier curves. Relative hazard ratios (HRs, 95\%CI) were used to estimate the risk of the outcome.

Results The patients, $n=99,87 \%$ females, were mean (SD) 47 (13) years old, had disease duration of 12 (9) years. The controls, $n=109$, 91\% females, were mean 49 (12) years old. Baseline carotid intima-media thickness (cIMT) did not differ between the groups. During 9.6 (1.5) years, 12 patients and 4 controls were documented with the outcome, $p=0.022$. Compared with the controls, the risk of the outcome in the patients was 3-4-fold increased at the same level of traditional $\mathrm{CV}$ risk factors and carotid measures. SLE-patients with poor outcomes had higher cIMT, SLICC, APS diagnosis and used prednisolone longer time than those without. Higher SLICC and APS diagnosis were associated with increased risk of the poor outcome, respective HRs 1,66 (1.20-2.28) and 9.08 (2.71-30.5), as well as with cIMT, HR 1.006 (1.002-1.01), independent of age and sex. The combination of SLICC and APS with cIMT significantly improved outcome prediction, $\mathrm{p}<0.001$.

Conclusions Patients with SLE compared with controls at the same level of CV risk factors and cIMT had increased long-term risk of clinical events. Applying accumulated disease-damage, APS and cIMT may improve risk stratification in SLE.

\section{P161 CASE REPORT OF A SYSTEMIC LUPUS ERYTHEMATOSUS AND ANTIPHOSPHOLIPID SYNDROME PATIENT WITH AN INFILTRATIVE TUBERCULOSIS AND MELANOMA: FEATURES OF THERAPEUTIC APPROACHES}

${ }^{1}$ Anastasiia Shumilova, ${ }^{1,2}$ Tatiana Reshetnyak, ${ }^{1,2}$ Fariza Cheldieva, ${ }^{1}$ Maria Cherkasova,

${ }^{1,2}$ Alexander Lila. ${ }^{1}$ Federal State Budgetary Scientific Institution 'Research Institute of Rheumatology named after V.A. Nasonova', Moscow; ${ }^{2}$ Federal State Budgetary Educational Institution of Further Professional Education 'Russian Medical Academy of Continuous Professional Education' of the Ministry of Healthcare of the Russian Federation, Rheumatology Academic Dept., Moscow, Russian Federation

\subsection{6/lupus-2020-eurolupus.203}

Background Systemic lupus erythematosus (SLE) is an autoimmune disease characterized by multiorgan tissue damage, including skin, that is frequently treated with high doses of immunosuppressive drugs. Thus, patients with SLE are at increased risk for infections (for example, tuberculosis) and malignancy. SLE and tuberculosis may have similar presentations and mimic each other; also, prior tuberculous infection may precipitate SLE in genetically predisposed individual. An increased standardized incidence ratio for non-melanoma skin cancer has been reported, however, there is no evidence of correlation between SLE and melanoma.

Methods We report a case of a patient with SLE and antiphospholipid syndrome (APS) with a moderate disease activity index $($ SLEDAI $=7)$ with infiltrative tuberculosis and melanoma.

Abstract P161 Table 1 Clinical and laboratory manifestations of the disease and treatment tactics

\begin{tabular}{|c|c|c|c|c|c|c|c|c|}
\hline$\underbrace{\text { Age }}_{\text {Manifestations }}$ & $\begin{array}{c}1996 \\
\text { (18 years old) }\end{array}$ & $\begin{array}{c}2000-2001 \\
(22-23 \text { years } \\
\text { old })\end{array}$ & $\begin{array}{c}2009-2010 \\
(31-23 \\
\text { years old }) \\
\end{array}$ & $\begin{array}{c}2011-2012 \\
(33-34 \text { years old) }\end{array}$ & $\begin{array}{c}2017 \\
\text { (39 years old) }\end{array}$ & $\begin{array}{c}\text { July } 2018 \\
\text { (40 years old) }\end{array}$ & $\begin{array}{l}\text { September } 2018 \\
\text { (40 years old) }\end{array}$ & $\begin{array}{c}2019 \\
\text { (41 years old) }\end{array}$ \\
\hline Photosensitivity & ! & & & & & & & \\
\hline Skin lesion & & & - erythema & - erythema & - erythema & $\begin{array}{l}\text { - cutaneous } \\
\text { neoplasm of the } \\
\text { lumbar region }\end{array}$ & & $\begin{array}{l}\text { - erythema and } \\
\text { subacute LE, herpes } \\
\text { zoster }\end{array}$ \\
\hline Oral ulcers & & & - & & - & & & n \\
\hline Alopecia & & & & & - & & & - \\
\hline Arthritis & & & & & & & & $\square$ \\
\hline Pericarditis & & & & - & & & & 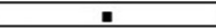 \\
\hline Hemolytic anemia & & & & - & - & & & \\
\hline $\begin{array}{l}\text { Highly positive } \\
\text { anticardiolipin } \\
\text { antibodies }\end{array}$ & - & & & - & & & & \\
\hline $\begin{array}{l}\text { Highly positive anti- } \\
\text { beta-2-glicoprotein } 1 \\
\text { antibodies }\end{array}$ & & & & - & & & & \\
\hline $\begin{array}{l}\text { Highly positive } \\
\text { antibodies to dsDNA }\end{array}$ & & & & - & - & & & - \\
\hline Smith antigen & & & & - & ! & & & $\square$ \\
\hline Hypocomplementemia & & & & - & - & & & $\square$ \\
\hline Additional information & $\begin{array}{l}\text { - False } \\
\text { positive } \\
\text { serological } \\
\text { test for } \\
\text { syphilis }\end{array}$ & $\begin{array}{l}\text { - Chest X- } \\
\text { ray: detection } \\
\text { of focal } \\
\text { changes in } \\
\text { the right lung }\end{array}$ & $\begin{array}{l}\text {-1st } \\
\text { Pregnancy } \\
\text { and } \\
\text { childbirth }\end{array}$ & $\begin{array}{l}\text { - 2nd Pregnancy and } \\
\text { childbirth } \\
\text { - Portal hypertension } \\
\text { as a manifestation of } \\
\text { microangiopathy of } \\
\text { APS }\end{array}$ & & & $\begin{array}{l}\text { mPET-CT: } \\
\text { infiltrative changes } \\
\text { in the upper lobe of } \\
\text { the right lung }\end{array}$ & \\
\hline Diagnosis & $\begin{array}{c}\text { No reliable } \\
\text { data was } \\
\text { obtained for } \\
\text { antiphospholi } \\
\text { pid syndrome } \\
\text { (APS) }\end{array}$ & $\begin{array}{c}\text { Focal } \\
\text { pulmonary } \\
\text { tuberculosis }\end{array}$ & - & $\begin{array}{c}\text { SLE } \\
\text { (Hematologic } \\
\text { diseases were } \\
\text { excluded). } \\
\text { APS }\end{array}$ & $\begin{array}{l}\text { SLE. } \\
\text { APS. }\end{array}$ & $\begin{array}{l}\text { Melanoma IB } \\
\text { T2NOM0. } \\
\text { SLE. } \\
\text { APS. }\end{array}$ & $\begin{array}{l}\text { Infiltrative } \\
\text { tuberculosis in the } \\
\text { upper lobe of the } \\
\text { right lung. } \\
\text { Melanoma IB } \\
\text { T2NOMO. } \\
\text { SLE. } \\
\text { APS. }\end{array}$ & $\begin{array}{c}\text { SLE. } \\
\text { APS. } \\
\text { Infiltrative tuberculosis } \\
\text { in the upper lobe of the } \\
\text { right lung. } \\
\text { Melanoma IB T2NOMO. }\end{array}$ \\
\hline Treatment tactics & $\cdot$ & $\begin{array}{l}\text { Antibacterial } \\
\text { therapy (drugs } \\
\text { and doses } \\
\text { unknown) }\end{array}$ & - & $\begin{array}{l}\text { Methylprednisolone } \\
12 \rightarrow 8 \mathrm{mg} / \text { day, } \\
\text { Hydroxychloroquine } \\
200 \mathrm{mg} \text { /day, } \\
\text { Nadroparin calcium } \\
0.6 / \text { day (6 months) }\end{array}$ & $\begin{array}{c}\text { Methylprednisolone } \\
16 \text { mg/day, } \\
\text { Hydroxychloroquine } \\
400 \mathrm{mg} / \text { day, } \\
\text { Mycophenolate } \\
\text { mofetil } 2 \mathrm{~g} / \mathrm{day}, \\
\text { intravenous pulse } \\
\text { methylprednisolone } \\
1500 \mathrm{~g} \text { No2 (in May } \\
\text { and August), } \\
\text { Rivaroxaban } 15 \\
\text { mg/day }\end{array}$ & $\begin{array}{c}\text { Melanoma excision } \\
\text { surgery. } \\
\text { Methylprednisolone } 8 \\
\text { mg/day, } \\
\text { Hydroxychloroquine } \\
400 \text { mg/day, } \\
\text { Mycophenolate } \\
\text { mofetil was canceled, } \\
\text { Rivaroxaban } 15 \\
\text { mg/day }\end{array}$ & $\begin{array}{c}\text { Methylprednisolone } 8 \\
\text { mg/day, } \\
\text { Hydroxychloroquine } \\
400 \text { mg/day, } \\
\text { Rivaroxaban } 15 \\
\text { mg/day, } \\
\text { Antibacterial therapy: } \\
\text { ('Pyrazinamide } 1500 \\
\text { mg/day, Cycloserine } \\
0.5 \text { g/day, } \\
\text { Sparfloxacin } 0.2 \\
\text { g/day, Linezolid } 0.6 \\
\text { g/day, Pprotionamide } \\
0.75 \text { q/day) }\end{array}$ & $\begin{array}{c}\begin{array}{c}\text { Methylprednisolone } 8 \\
\text { mg/day, }\end{array} \\
\text { Hydroxychloroquine } 400 \\
\text { mg/day, } \\
\text { Rivaroxaban } 15 \mathrm{mg} / \text { day, } \\
\text { intravenous pulse } \\
\text { methylprednisolone } 1500 \\
\text { g No2 (in May and } \\
\text { December), intravenous } \\
\text { immunoglobulin } 20 \mathrm{~g} \text { (in } \\
\text { December), Antibacterial } \\
\text { therapy: ( ( ), Acyclovir } 4 \\
\text { g/day } 10 \text { days }\end{array}$ \\
\hline
\end{tabular}


Results A 41-year-old female patient with SLE for 22 years, was diagnosed on the basis of skin lesion, alopecia, photosensitivity, oral ulcers, arthritis, pericarditis, hemolytic anemia, leukopenia, highly positive antibodies to dsDNA, hypocomplementemia, ANF hep-2 positivity. An anamnesis of the disease and treatment tactics are presented in table 1.

Conclusions There are no established guidelines available for treatment of tuberculosis or melanoma in SLE patients due to lack of relevant studies and management based more on physician expertise. The use of genetically engineered biological drugs can be limited due to the high risk of infection, the onset of cancer in the anamnesis, and also not fully studied in patients with comorbidity.

\section{P162 PROGRESSION OF SUBCLINICAL CARDIOVASCULAR DISEASE IN SLE: A FIVE YEAR FOLLOW UP STUDY}

\author{
${ }^{1}$ Jyoti Bakshi, ${ }^{2}$ Maura Griffin, ${ }^{1}$ Sara Croca, ${ }^{1}$ Filipa Farina, 'David Isenberg, \\ ${ }^{2}$ Andrew Nicolaides, ${ }^{1}$ Anisur Rahman. ${ }^{1}$ Dept. of Medicine, Centre for Rheumatology \\ Research, UCL, London; ${ }^{2}$ Vascular Noninvasive Diagnostic Centre, London, UK
}

10.1136/lupus-2020-eurolupus.204

Background SLE patients have 5-10-fold increased risk of developing CVD compared to controls. ${ }^{1,2}$ In this study we aimed to describe the rate and determinants of carotid plaque progression in a cohort of SLE patients who were asymptomatic of CVD at baseline.

Methods Vascular ultrasound studies of 100 patients with SLE asymptomatic of CVD was carried out at baseline. Sixty-nine patients were rescanned (94\% female, mean overall age 46 years (SD 11)) over a median of 5 years of follow up. Clinical and CVD risk was assessed at baseline and follow up. Bmode Doppler ultrasound was used to measure intimal media thickness and plaque to assess progression. Total plaque area (TPA), a more sensitive measure of plaque, and echolucency expressed as gray scale median (GSM), linked to plaque lipid content were assessed.

Results Of the 100 patients with a baseline scan, 69 patients had a second scan at a median of 5 years follow up. New plaque developed in $9 \%$ and $26 \%$ had an increase in plaque number. The mean overall IMT $(0.111$ vs $0.064, \mathrm{p}<0.01)$ and common carotid IMT $(0.065$ vs $0.055, \mathrm{p}<0.01)$ were significantly raised in plaque vs non-plaque patients. In a multi -variable analysis CIMT at follow-up was independently associated with age (beta $0.415, \mathrm{p}<0.001$ ) and diastolic blood pressure (beta 0.285, $\mathrm{p}<0.021$ ). Independent predictors of plaque at follow-up scan on multi-variable analysis were age at scan $>52$ years (OR 10.41, CI 2.6640.80) and systolic BP>133 (OR 5.26, CI 1.396 - 19.862). In contrast, total cholesterol was negatively correlated with TPA (beta $=-1.167, p=0.002$ ) and with GSM (beta =$0.513, \mathrm{p}=0.012)$.

Conclusions Amongst these 69 patients, 26\% had progression and none had decreased plaque over a median of five years follow-up. Measurement of novel ultrasound variables such as TPA and echolucency may identify more modifiable risk factors that can be used to improve CVD outcomes in patients with SLE.

Acknowledgements Rosetrees Trust

\section{REFERENCES}

1. Bruce IN. 'Not only...but also': factors that contribute to accelerated atherosclerosis and premature coronary heart disease in systemic lupus erythematosus. Rheumatology (Oxford, England) 2005;44(12);1492-502.

2. Manzi $\mathrm{S}$, Meilahn EN, Rairie JE, et al. Age-specific incidence rates of myocardial infarction and angina in women with systemic lupus erythematosus: comparison with the Framingham Study. Am J Epidemiol 1997;145(5);408-15.

\section{P163 IMPROVING A SLE-QUALITY INDICATOR TOOL IN AN OUTPATIENT TERTIARY CARE SETTING}

${ }^{1} J u n$ Chu, ${ }^{1}$ Elaine Poncio, 'Isabel Ochoa, ${ }^{1}$ Yenealem Temesgen-Oyelakin, ${ }^{1}$ Michael Davis, ${ }^{1,2}$ Sarthak Gupta, 'Zerai Manna, 'Marquis Chapman, 'Eileen Chu, ${ }^{3}$ Aidan Donnellan, ${ }^{1}$ Sarfaraz Hasni. 'Lupus Clinical Research Program, National Institute of Arthritis and Musculoskeletal and Skin Diseases (NIAMS), Bethesda; ${ }^{2}$ Systemic Autoimmunity Branch, NIAMS, Bethesda; ${ }^{3}$ Clinical Center Volunteer, NIAMS, Bethesda, USA

\subsection{6/lupus-2020-eurolupus.205}

Background The care for patients with lupus is complex as they may exhibit multiple concomitant medical and socioeconomic issues. To address all their needs according to the current guidelines is a daunting task in busy outpatient practices. However, incorporating quality indicators in patient care has been found to decrease mortality and morbidity, improve patient satisfaction, and reduce costs. To improve the quality of care following recommendations from published guidelines, ACR, and EULAR, we embarked on a comprehensive quality improvement project by developing a checklist tool that incorporates the major SLE-Quality indicators (SLE-QI).

Method The project was launched in October 2017. A SLEQI checklist detailing quality indicators was created based on published recommendations for standard of care. The checklist included a set of 20 SLE-QIs that address several important aspects of SLE care including diagnosis and disease monitoring, general prevention strategies, screening for comorbidities, drug toxicity monitoring, assessment of renal disease, reproductive health, and quality of life in daily practice. A standardized document template for clinic visits was developed that incorporated these quality indicators. Clinic progress notes were reviewed weekly to determine if these indicators were used and addressed. If SLE-QIs were missing, efforts were made to reach out to providers to address the missing QIs.

Results At the beginning of the assessment, documentation of SLE-QIs was generally poor and inconsistent. For example, vaccinations was only at $60 \%$ compliance while screening for cardiovascular risk was only at 3\% compliance. Since documentation was not standardized, it was difficult to assess if SLE-QIs were being done. Implementing SLE-QI in standardized notes resolved these concerns, bringing compliance close to $100 \%$ compliance for the 20 identified SLE quality indicators.

Conclusion Standardized progress notes incorporating QI indicators is a feasible strategy that helps streamline data extraction for future clinical research. Additionally, incorporating patient outcome tools improves the ability to perform treat-totarget strategies for SLE. This ongoing QI project may potentially improve overall patient outcomes and lead to reduce health care costs. 